\title{
Of Hosts \& Guests: Curricular Discourses at a Southeast Asian Cultural Village
}

\section{Cameron Graham}

This paper explores the ways tourist-visitors and personnel at "Cultural Villages" (whom I call, after Smith's (1989) work, Hosts and Guests, respectively) might engage in processes of informal learning and meaning making through their exchanges, and their interaction with promotional literature, activities, artifacts, performances, and the architecture of the cultural village site. Having not yet found a definition of a Cultural Village in the available literature, I will offer my own: Cultural Villages (known also as "Living Museums") could be characterized as commercial and/or heritage sites where a particular time, place and culture is "reconstructed" in a contemporary context. Within, museum personnel--often members of the groups featured at the museum (be they ethnic, tribal or trade oriented)--perform various characteristic cultural activities for visitors. Such institutions have become a widespread phenomenon in southeast Asia in recent years. Both Hosts and Guests, I suggest, bring pre-formed ideas, attitudes and expectations to their interactions, which can be partially interpreted through reference to theories of memory, meaning-making, and the anthropology of tourism.

These complex processes could constitute an informal curriculum frameable within contemporary curriculum theories. Curricula occur in Schubert's (1986) and Cremin's (1961, 1976) opinion, at sites as diverse as churches, temples, media and businesses; even day care centers and families possess their own curricula. Davis and Sumara (1997) concur, observing that similar activities occur at "shopping malls, restaurants, food banks, retirement homes, churches, festivals, hockey games, etc." (p.123). I will argue that discourses of Authenticity are central to interpretations of the curriculum of the Sarawak Cultural Village, near Kuching, in east Malaysia--where I am doing my doctoral research.

\section{Museum Metamorphoses}

Although a cultural village might not possess all the attributes of the "traditional" museum, it does exemplify the diversifying of the museum model; for as Lisa Roberts (1994) suggests:

There is no 'true museum'. Rather, there is an ongoing argument about what properly constitutes the institution and its activities...Museum history is a tale of conflicting philosophies and institutional manifestations. Indeed, it is out of such conflict and argument that museums lumber forward, change, and grow. (p.154)

Moreover, the proliferation of "heritage parks", "cultural villages" and "living museums"--to mention but a few of the names the current crop of outdoor museums have generated--has ensured that "the distinction between a museum 
and a tourist site is not always clear, and the two often overlap. Colonial Williamsburg and Lincoln's New Salem are outdoor museums as well as tourist attractions" (Bruner, E. 1993, p.6). Graburn (1983) states;

Museums are the sine qua non of the packaging of our understanding of culture, history, nature, geography etc., and have a history and functions that are inseparable from tourism itself...from world's fairs and theme parks to local and ethnic events". (p.26)

Graburn suggests that museums (in their many guises) and tourism are inextricably linked, and are influential in shaping contemporary understandings of heritage and culture. Exploring how a specific cultural village "packages" culture, how tourists and site personnel interact with the representations they experience and each other, and what understandings are established, necessitates a flexible, pragmatic orientation to the research endeavor.

At the Sarawak Cultural Village, complex interactions occur on a daily basis between administrators, personnel, tourists, tourist guides and a host of different kinds of visitors. Their exchanges and interpretations are coloured by their preconceptions, the nature of their relationships, the reasons for their being on-site, what they experience whilst there, and the design/architecture of the site itself. To discover the curricular discourses at work within this milieu entails a study of key actors and artifacts, and enquiries into their interrelationships. LéviStrauss' (1976) notion of Bricolage illuminates the inherently site-specific, adaptive qualities of such an approach.

\section{Biography, Bricolage and the Case}

Consider him at work and excited by his project. His first practical step is retrospective. He has to turn back to an already existent set made up of tools and materials, to consider or reconsider what it contains and, finally and above all, to engage in a sort of dialogue with it and, before choosing between them, to index the possible answers which the whole set can offer to his problem. He interrogates all the heterogeneous objects of which his treasury is composed to discover what each of them could 'signify' and so contribute to the definition of a set which has yet to materialize... (Lévi-Strauss, 1976, p.18)

So Lévi-Strauss describes the bricoleur at work. Within the research canon, that "existent set" is the researcher's ideas, attitudes and theories, based on his informal recollections and formal schooling in the discipline. The treasury is his repertoire of useful ideas and techniques. In this section I will describe how the concept of bricolage provides a valuable metaphor for the biographic underpinning of culturally-oriented studies such as my own. 
My own life history has led me toward the research question. Having acquired various values, attitudes and beliefs, I possess a particular interest in, and approach to, my research. Denzin and Lincoln (1994) observe that; "qualitative researchers self-consciously draw upon their own experiences as a resource in their inquiries. They always think reflectively, historically, and biographically" (p.199). Qualitative educational research also refers to the significance of biography (Butt, 1985; Connelly \& Clandinin, 1987). A Borneo resident of almost five years standing from 1990 until 1994, I worked as an art and design lecturer in Brunei Darussalam, and also as a freelance writer. Focusing on cultural issues, I covered arts events, festivals, and the work of local artists in east Malaysia (Sarawak and Sabah) and Brunei Darussalam. This enabled me to establish many contacts in the regional arts community. These connections have been maintained during my Canadian study sojourn. My acquaintance with the Sarawak Cultural Village came via this informal network of associations. Moreover, I have family connections in the area, further cementing my commitment to the region.

The resourceful use of personal knowledge and connections in research can be construed as a form of intellectual bricolage. The bricoleur was formerly interpreted, according to Lévi-Strauss (1976), to be analogous to the odd-job man who, making use of the materials at hand creates new objects and structures in the process: "The bricoleur is adept at performing a large number of diverse tasks... His universe of instruments is closed and the rules of the game are always to make do with 'whatever is at hand', that is to say with a set of tools and materials which is always finite and is also heterogeneous" (p.17). Since Levi-Strauss' (1976) observations, this notion of "handiness" has been attributed to the role of cultural researchers, in their everyday encounters with difference. Indeed, Roberts, M. (1994) observes: "...bricolage ... was subsequently to prove... influential as a model for the interpretation of cultures, whether 'civilized' or 'primitive'"' (p.11).

"On site", the researcher-bricoleur will adaptively phrase his questions, sensitive to his on-site encounters. Consequently, the inquiry techniques used, and subsequent interpretations are likely to change to some extent, as structures of meaning are built, found wanting, and erected in different forms:

An implicit inventory or conception of the total means available must be made...so that a result can be defined which will always be a compromise between the structure of the instrumental set and that of the project. Once it materializes the project will therefore inevitably be at a remove from the initial aim (which was moreover a mere sketch). (Lèvi-Strauss, 1976, p.21)

The bricoleur-researcher is participative, and herice deeply involved in the case. This involvement is inherently reflective, though steeped in the particular epistemological frame and research tradition which he brings to the milieu: "The researcher-as-bricoleur is always already in the empirical world of experience. Still, this world is confronted, in part, through the lens that the

Marilyn Zurmuehlen's Working Papers In Art Education 1996-1997 
scholar's paradigm, or interpretative perspective, provides" (Denzin \& Lincoln, 1994, p.199).

Indeed, the researcher-as-bricoleur acknowledges the significance of his own life history in all stages of the research process:

The 'bricoleur'...does not confine himself to accomplishment and execution: he speaks not only with things... but also through the medium of things: giving an account of his personality and life by the choices he makes between the limited possibilities. (Levi-Strauss, 1976, p.21)

The work of the researcher-bricoleur is inherently process--rather than product-oriented. However, his presence in the research is evident: "[the]'bricoleur' may not ever complete his purpose but he always puts something of himself into it" (p.21).

My background will govern the questions I ask, of whom I ask them, and my ensuing interpretations. Walton (1992) acknowledges the idiosyncratic, personal motivations which undergird research choices: "In actual research practice...cases are chosen for all sorts of reasons, from convenience and familiarity to fascination and strategy" (p. 125). Nevertheless, whilst motivated by a host of personal reasons, the question once chosen "must be justified...shown to be a case of something important" (p.125). By inquiring into the curricular discourses of a southeast Asian Living Museum therefore, I make the claim that something worthwhile and illuminative will be discovered through my research. Ross (1994) neatly encapsulates the personal orientation toward studies involving human participants, alerting us to the need for an ethical standpoint informed by an awareness of potential pitfalls. He also reminds us that the subsequent ideas arising from such studies should prove to be useful, and innovative:

The most honest, or least delusory, path is to accept that writing about others (nothing will silence this desire) is usually autobiographical, and hope that the self-indulgence carries over, mutatis mutandis, into some useful region of thought and action for which there are no guaranteed navigational $\mathrm{co}^{-}$ ordinates. (p. 29)

My earnest hope is that, through my research at the Sarawak Cultural Village, I will not only advance museum and tourist education theory, but also help establish new cultural links--professional and informal--between Canada and southeast Asia. Such pan-Pacific link-ups are increasingly valued internationally, both in educational and wider cultural fora. Furthermore, I believe my work will help promote interdisciplinarity and qualitative orientations toward educational inquiry. 


\section{Meaning, Intersubjectivity and the Case}

A theoretical overview informing my interviews with Hosts and Guests will be Silverman's (1995) notion of meaning-making. Originally directed toward the learning styles of museum visitors, I will suggest that the concept also bears upon the practice of case study research at a cultural village.

At living museums visitors, in their encounters with performances, objects and architecture emblematic of certain cultures, experience learning events. However, they also bring their own preconceived ideas to their experience of the living museum. These ideas are grounded in culturally and personally determined conceptions of what constitutes a museum experience and what learning about other cultures might mean within these contexts.

Meaning-making draws from elements of discourses such as post modernism, constructivism and contemporary literary theory. Communication-from a postmodern standpoint--is conceptualized in non-linear terms, so the various communications of museums are considered processes of negotiation in which new meanings are created, rather than as acts of linear transmission from museum "insiders" to visitors. Meaning-making was described by Silverman (1995) as:

the visitor's active role in creating meaning of a museum experience through the context she/he brings, influenced by the factors of self-identity, companions and leisure motivations. As a result, visitors find personal significance within museums in a range of patterned ways that reflect basic human needs, such as the need for individualism and the need for community. (p.161)

Visitors to museums make meaning through an ongoing process of remembering and connecting. A body of theory (Silverman, 1995; Falk \& Dierking, 1992; Hermann \& Plude, 1995) supports this view. These scholars have suggested that perception and learning hinge upon the accommodation of new information into existing mental structures and frameworks. Similarly in museums, people attempt to place what they encounter--be it text, object, or graphic communication--within the context of their previous experiences.

Memories and ideas are not exclusively the domain of individual experience; they are also formed collectively, and communally. In a number of museum visitor surveys, it has been concluded that people tend to visit in groups rather than on an individual basis: "Seventy-five to ninety-five percent of visitors encounter museum artifacts in the company of others, over one third in pairs. Most often, visitors are in the company of loved ones, such as partners, relatives and friends" (Silverman 1995, p.163). Within such groups, collective and individual meanings are established (Diamond, 1986; Dierking, 1989; Falk, 1991; McManus, 1987; Rosenfeld, 1980). 
The establishment and (re)affirmation of shared memories and ideas has been described by Wells (1991), Rommetveit (1985), Coles (1978), Schutz (1970) and Percy (1954) as Intersubjectivity. Coles writes: "Intersubjectivity has to do with knowledge and meaning--insofar as both, in turn, have to do with individuals directly or indirectly calling upon one another for assistance, and, not least, rejoicing together when the appeal is successful" (1978, p.72). Schutz (1970) observes:

the world of my daily life is by no means my private world but is from the outset an intersubjective one, shared with my fellow men, experienced and interpreted by others; in brief, it is a world common to all of us. The unique biographical situation in which I find myself within the world at any moment of my existence is only to a very small extent of my own making. (p. 164-5)

Schutz maintains that the worlds of our daily lives are interpreted by others. Their interpretations become part of our experience of them, and thus, reshape the meanings which we establish. He also suggests that only a small part of individual knowledge emanates from personal experiences. Socially-formed knowledge predominates; such knowledge comes from friends, acquaintances, family, teachers and the like.

Wells (1991) highlights the shared intention which characterizes intersubjectivity. He identifies the; "mutual belief of the participants in an interaction that, by virtue of the uttering and uptake of communicative acts, they are jointly attending to the same aspect of the situation in which they are involved" (p.6). He also refers to the often long process of negotiation which finally ensures intersubjectivity, and the importance of the cultural context in that process:

Intersubjectivity is verbally negotiated over a considerable stretch of discourse and, in others, it is implicitly assumed on the basis of presuppositions which each participant has built up over his or her whole lifetime, as a result of membership of a number of cultural groups. (P.6)

In my relationship with cultural village personnel, management and administrators, I will be engaging in conversations not only designed to find out more about a particular issue; I will also be negotiating a range of shared, intersubjective meanings which will allow us to further our discourse about the Sarawak Cultural Village. Equally, in my conversations with personnel and visitors alike, I will be drawing on a repertoire of shared, long-term assumptions which allow us to meaningfully communicate. Within this context, my own history--and its resonance with the lives of the people with whom I speak--will be of profound importance.

Zurmuehlen (1981) describes the special significance and meaning she derives from her experience of an Egyptian make-up box at the Cleveland 
Museum of Art, noting the elements of her biography which enable her to establish significant meaning around the event. and in the physicality of the box itself. Describing the personal meanings with which the box is for her, imbued, she writes: "Centainly you realize it is mine. I cannot know for how many others it also is theirs. But I take comfort in understanding that it belongs to such a community of us" (p.26). Zurmuehlen also invokes Boas' (1950) conception of how we find meaning in art objects, wherein the piece plays a provocative role as "have[ing] become, above all, an invitation to interpretation" (Boas, p.313).

In its staged re-presentations of architecture, community, artifact, ceremony and activity. I would suggest that a cultural village also issues a similar challenge to interpret and understand to host, guest and researcher alike. Multiple, negotiated intersubjectivities are likely to ensue from the experience of the cultural village. These complex understandings will likely reflect the way individual meaning is shaped by group consensus and discord. This could be said to exemplify the process of meaning-making which the individual-as-groupmember undergoes.

Through my research I engage in my own process of making meaning about the Sarawak Cultural Village. My intersubjective understandings about the research event will emerge from my biography in its entirety. Particularly significant will be the meanings established with my prior research community, and my main contacts on-site. Ultimately, what I learn will be shaped through incidents which occur during the research "adventure", and might differ radically from my initial expectations. My writing will mark and interpret these incidents for others to read. Stake (1994) alludes to the transformations of meaning which occur during the writing process: "Case content evolves in the act of writing itself" (p.240). Readers will also derive new meaning from their interpretation of the study, hopefully gaining an enriched conception of the phenomenon: "The reader comes to know some things told, as if he or she had experienced them. Enduring meanings come from encounter, and are modified and reinforced by repeated encounter" (p.240). They will also have brought their own previously established meanings to their experience of the text, which will further modify consequent understandings.

Silverman (1995) describes how museum visitors contextualize their experience within the broader fabric of prior memories. Therefore, memory is key to the process of meaning making: "visitor studies as well as informal observation in galleries suggest that, through memory, visitors bring forth past experience ...to shape present meaning" (p.162). Special knowledge expectations and norms, and life events and situations are deemed to be specially significant as types of memory brought into play within current museum experiences. Resultant interpretations yield fresh meaning which, as humans, we wish to convey to others; this would apply equally to hosts, guests and researchers, although the form and content of that expression might differ markedly. Three factors, according to Silverman are especially significant: Self identity, companions, and leisure motivations and benefits. Self identity refers to our need to affirm--whatever the activity--not only our sense of self, but also our relationship-as-self with the group of which we are a member. In general, we 
tend to visit museums as members of groups (Draper, 1984). Consequently, "as in so many other realms of human life, people create content and meaning in museums through the filter of their interpersonal relationships" (Silverman, 1995, p.163). Finally, leisure motivations fulfill a variety of human needs which Graburn (1983) defines as reverential (an out-of-the-ordinary, "sacred" experience), associational (an opportunity to gather socially), and educational (a chance to learn).

The above characterization of meaning-making in the museum can be readily adapted to the living museum visit, as the same phenomenon of self-asleisure group member is likely to shape meanings arrived at during the cultural village tour. How then, can the researcher discover these new meanings through his interactions with tourists and personnel? The interview, which is at the center of my research strategy, offers one means.

\section{"Authentic" Questions}

For ethnographers, tourists, and indigenous peoples the question is not if authenticity is inherent in an object, as if it were a thing out there to be discovered or unearthed, but rather, how is authenticity constructed? What is the process by which an ethnography, a tourist performance, or an item of culture or practice achieves an aura of being authentic? What are the processes of production of authenticity? Just as ethnicity is a struggle... authenticity, too, is something fought over, and reinvented. (Bruner, E., 1991b., p.326)

Central to my study of the Sarawak Cultural Village case are the questions guiding, and limiting the parameters of my research. My key questions inquire into the discourses of Authenticity occurring at the village. A discourse can be defined in structural and post-structural terms as "a discursive practice which itself forms the objects of which it speaks... it exists at the level of "it is said"' (Pinar, Slattery, Taubman, 1995, p.462). Discourses run through various disciplinary boundaries; therefore, "one can speak... of a psychological discourse, a medical discourse, a curriculum discourse, or one can speak of a discourse on madness or sexuality" (p.462). Consequently, discourses can also run through each other, creating new meanings and discursive events. As a culturally defined confluence of meaning, authenticity is an influential issue in contemporary life. Within a cultural village milieu, museum, tourism and curricular discourses intertwine. Significantly, they each appropriate discourses of authenticity, to which I shall now refer.

\section{Tourism Authenticities}

Tourism anthropologists have discussed the role of the authentic in tourism for more than twenty years. Leading scholars in the field Dean MacCannell, Erik Cohen and Edward Bruner interpret authenticity in tourism in a variety of illuminating ways. MacCannell's (1976) contribution is grounded in the premise that tourists seek escape from the alienation and meaninglessness of 
contemporary life. Tourism provides an opportunity to experience the authenticity of the pristine, primitive and natural, through a pilgrimage to that which is so far untouched by the "modern". Cohen (1988) however, proposes that "authenticity is a socially constructed concept and its social connotation is, therefore, not given, but 'negotiable"' (p.374). Authenticity could then be construed to be a personally constructed, contextual, and changing concept. Tourists are thus active creators of meaning in their tourism experiences, rather than passive recipients. Bruner (1991a) proposes that not all tourists are alienated from their worlds nor are they all seeking MacCannell's notion of the authentic experience. Instead, Bruner suggests that some tourists might find a "commercialized replication of local customs" (Cohen, 1988, p.378) a sufficiently authentic product. Bruner describes these products as "authentic reproductions" (1991a, p.240-1).

\section{Museum Authenticities}

Historically, the aura of authenticity surrounding museum

(re)presentations has depended on that institution's authoritative role as a cultural arbiter of value. Indeed, Crew \& Sims (1991) argue that;

Authenticity is not about factuality or reality. It is about authority. Objects have no authority; people do...Authenticity-authority--enforces the social contract between the audience and the museum, a socially agreed upon reality that exists only as long as confidence in the voice of the exhibition holds.

(p. 163)

Duncan (1991) suggests that this social contract has enabled the museum visit to become a western ritual of good citizenship: "The West...has long known that...museums are important, even necessary, fixtures of a well-furnished state" (p.88).

Cameron (1971) identifies two distinct stances that museums have assumed vis à vis their role as cultural arbiters of authenticity. The first, arguably more traditional role of the museum is seen as that of a temple, where it plays a "timeless and universal function, [and uses] a structured sample of reality, not just as a reference but as an objective model against which to compare individual perceptions"(p.201). The second position is that of the museum-as-forum, a place which becomes a focus for "confrontation, experimentation, and debate" (p.197). In its temple role, the museum confers authenticity not only on the artifact, but also on its unambiguous public contemplation. Within the museumas-forum setting however, the status of the artifact and the way it is viewed are reflected on, and its assumptions critiqued.

Significantly for cultural villages and their like, Crew and Sims (1991) do not locate authenticity in the appreciation of an isolated artifact. Rather they situate it within the act of visiting a museum or cultural village. Moreover, the visitor is not seen as a passive recipient. Instead she is considered to be an active co-creator of meaning: "It is the event that is primary, not the things or even our 
directed thoughts about them. And it is in the place/time of the event that the audience takes part, becoming cocreators of social meaning. Authenticity is located in the event" (p.174).

\section{Curriculum Authenticities}

Mature scholars and beginning students alike have bemoaned the plethora of definitions [of curriculum]. We do not see this as a terrible problem. A complex field will use central terms in complex, sometimes even contradictory, ways. (Pinar, Slattery, Taubman, 1995, p. 26)

Within the limits of my research, I will also accept the innate complexities of contemporary curricular debate. Curriculum will be understood as being comprised of diverse discourses, each of which furthers its own "territorial" conception of curricular authenticity. In this context, the curriculum is not to be understood as a process of linear transmission of knowledge, ideas and attitudes. Rather, it is a site of contentious communication between diverse groups, from which a host of meanings emerge. Davis and Sumara (1997) explore this dynamic conception of curriculum: "Teaching and Learning must be understood as simultaneously shaping and being shaped by the circumstances in which they occur" (p.122). They also highlight the inherently adaptive, ubiquitous quality of curriculum: ''Teaching' and that which we call 'learning' might be better understood as mutually specifying, co-emergent, pervasive, and evolving practices that are at the core of our culture's efforts at self-organization and selfrenewal" (p.123). They also argue that curricular discourses emerge at locations unfamiliar with the practices of mainstream educational institutions:

Rejecting the cultural arrogance underlying the belief that the formal educational setting is the principal location for the study of cultural knowledge, we are suggesting that other sites be seen as places of teaching and learning: shopping malls, restaurants, food banks, retirement homes, churches, festivals, hockey games, etc. (p.123)

My own territorial vantage point is to understand the curriculum of the Sarawak Cultural Village (which could be comfortably added to Davis' and Sumara's [1997] list of sites of non-formal pedagogy), as being situated within MacLaren's (1991) notion of culture-as-discourse, and hence a ground of change, resistance, and transformation.

Forms of identity are promulgated--or resisted--at institutions like schools, museums and cultural villages. These representations are significant as such institutions carry the stamp of institutional authority, and hence authenticity: "Representation becomes important, then, not only because it reflects identity at a particular historical conjuncture; it is important because it also creates that identity" (Pinar, Slattery and Taubman 1995, p.346). Cultural Villages and their attendant curricular discourses rely on the idea of "authentic reconstruction", in which buildings, activities and costumes are re-constructed to traditional forms in 
an appeal to the authority of history. This exemplifies the idea of the simulacrum, which is "the identical copy for which no original ever existed," (Jameson 1991, p.18). Interpreting Jameson's position, Pinar, Slattery and Taubman (1995) comment,

we see in the postmodern era a proliferation of theme parks which reconstruct, for instance, colonial villages, or Disney versions of older historical and architectural styles, or we see the "historical" docu-drama which produces historical images for which no real signified exists except in the form of other signifiers and interpretations. (p.471)

We thus encounter a site wherein a curriculum of "authentic" reconstruction of buildings, objects, events and ceremonies is enacted, although no original template exists. However, the transmission of such an authentic discourse is problematic. Conceptions of authenticity pertaining to the cultural village experience are likely to vary amongst involved actors, thus producing a complex web of meaning surrounding the event. It is this complex web with which my study is concerned, and which I will endeavor to make meaningful to subsequent readers.

\section{References}

Boas, G. (1950). The Problems of Meaning in the Arts. University of California Publications in Philosophy 25, 11. Berkeley, CA: University of California Press.

Bruner, E. (1991a). Transformation of Self in Tourism. Annals of Tourism Research 18, 238-250.

Bruner, E. (1991b). Epilogue: Creative Persona and the Problem of Authenticity. In S. Lavie, K. Narayan, Rosaldo, R., (Eds.), Creativity/ Anthropology (pp. 321-334). Ithica and London: Cornell University Press.

Bruner, E. (1993). Introduction: Museums and Tourism. Museum Anthropology, 17, 3, 6 .

Butt, R. (1985). Biography and Personal Practical Knowledge. Paper presented at the annual meeting of the Canadian Society for the Study of Education, Montreal PQ.

Cameron, D. (1971). The Museum: A Temple or the Forum. Journal of World History 14, 1, 201.

Cohen, E. (1988). Authenticity and Commoditization in Tourism. Annals of Tourism Research 15, 371-386.

Coles, R. (1978). The Search. The New Yorker, October 2. 43-109. 
Connelly, M. and Clandinin, J. (1987). On Narrative Method, Biography and Narrative Unities in the Study of Teaching. The Journal of

Educational Thought, 21:3, pp. 130-139.

Cremin, L. (1961). The transformation of the school: Progressivism in American education 1876-1957. New York: Vintage.

Cremin, L. (1976). Public Education. New York: Basic Books.

Crew, S.R. and Sims, J.E. (1991). Locating Authenticity. In I. Karp and S.D. Lavine (Eds.), Exhibiting Cultures: The Poetics and Politics of Museum Display (pp. 159-175). Washington, DC: Smithsonian Press.

Davis, B. and Sumara, D. (1997). Cognition, Complexity, and Teacher Education. Harvard Educational Review 67, 1, 105-125.

Denzin, N.K., and Lincoln, Y.S. (1994). Strategies of Inquiry. In N.K. Denzin, and Y.S. Lincoln (Eds.), Handbook of qualitative research (pp.199-352). California: Sage.

Diamond, J. (1986). The Behavior of family groups in science museums.

Curator, 29 (2), 139-154.

Dierking, L.D. (1989). The family museum experience: Implications from research. Journal of Museum Education, $14(2), 9-11$.

Draper, L.L. (1984). Friendship and the Museum Experience: The Interrelationship of Social Ties and Learning. Unpublished dissertation, University of California at Berkeley.

Duncan, C. (1991). Art Museums and the Ritual of Citizenship. In I. Karp and S.D. Lavine (Eds.), Exhibiting Cultures: The Poetics and Politics of Museum Display (pp. 88-103). Washington, DC: Smithsonian Press.

Falk, J.H. (1991). Analysis of the Behavior of Family Visitors in Natural History Museums. Curator 34/1. pp. 44-50.

Falk, J., and Dierking, L. (1992). The Museum Experience. Washington, DC.: Whalesback Books.

Graburn, N.H. (1983). The Anthropology of Tourism. The Annals of Tourist Research 10,3.9-33.

Herrmann, D., and Plude, D. (1995). Museum Memory. In John H. Falk and Lynn Dierking (Eds.), Public Institutions for Personal Learning (pp.

53-66). Washington, DC: American Association of Museurns. 
Jameson, F. (1991). Postmodernism and the cultural logic of late capitalism. Durham, NC: Duke University Press.

Levi-Strauss, C. (1976). The Savage Mind. London: Weidenfeld and Nicholson.

MacCannell, D. (1976). The Tourist: A New Theory of the Leisure Class. New York: Schoken Books.

McLaren, P. (1991). Decentering culture: Postmodernism, resistance and critical pedagogy. In N. Wyner (Ed.), Current perspectives on the culture of schools (pp. 231-257). Boston, MA: Brookline Books.

McManus, P. (1987). It's the company you keep. The social determination of learning-related behavior in a science museum. International Journal of Museum Management and Curatorship 6.

Percy, W. (1954). Symbol as Hermeneutic in Existentialism. Philosophy and Phenomenological Research, June. 523-550.

Pinar, W., Reynolds, W., Slattery, P., Taubman, P. (1995). Understanding Curriculum. An Introduction to the Study of Historical and Contemporary Curriculum Discourses. New York: Peter Lang.

Roberts, L. (1994). Rebuttal to "Are Museums Still Necessary? Cu rator 37, 3, 152-154.

Roberts, M. (1994). Michel Tournier: Bricolage and Cultural Mythology. Saratoga, CAL: ANMA Libri.

Rommetveit, R. (1985). Language acquisition as increasing linguistic structuring of experience and symbolic behavior control. In J. Wertsch (Ed.), Culture, Communication, and Cognition: Vygotskian Perspectives. UK: Cambridge University Press.

Rosenfeld, S. (1980). Informal Learning in zoos: Naturalistic studies of family groups. Unpublished doctoral dissertation, University of California, Berkeley.

Ross, A. (1994). The Chicago Gangster theory of life: Nature's debt to society. London; New York: Verso.

Schubert, W. (1986). Curriculum: Perspective, paradigm, and possibility. New York: Macmillan.

Schutz, A. (1970). On Phenomenology and Social Relations. Chicago: University of Chicago Press. 
Silverman, L. (1995). Visitor Meaning-Making in Museums for a New Age. Curator $38,3,161-170$.

Smith, V., (Ed.). (1989). Hosts and Guests: The Anthropology of Tourism. Philadelphia: University of Pennsylvania Press.

Stake, R.E. (1994). Case Studies. In N.K. Denzin and Y.S. Lincoln (Eds.), Handbook of qualitative research (pp. 236-247). California: Sage.

Walton, J. (1992) Making the theoretical case. In C.C. Ragin and H.S. Becker (Eds.), What is a Case? Exploring the foundations of social inquiry (pp. 121-138). New York: Cambridge University Press.

Wells, G. (1991). Intersubjectivity and the construction of knowledge. Ontario Institute for Studies in Education. 1-20.

Zurmuehlen, M. (1981). How Art Gives Meaning to Experience. Art Education, Vol. 34, 4. 24-26. 